\title{
UJI SENSITIVITAS ANTIBIOTIK TERHADAP BAKTERI Aeromonas hydrophilla DAN Edwardsiella tarda SKALA LABORATORIUM (INVITRO)
}

Genta Sapta Bayu Perkasa, Armen Nainggolan, Yudha Lestira Dhewantara Fakultas Perikanan dan Ilmu Kelautan, Universitas Satya Negara Indonesia.

\begin{abstract}
ABSTRAK
Bakteri Aeromonas hydrophilla dan Edwardsiella tarda merupakan bakteri yang berbahaya bagi budidaya ikan air tawar. Penelitian ini bertujuan untuk mengetahui dan membandingkan daya hambat dan sensitivitas bakteri Aeromonas hydrophilla dan Edwardsiella tarda terhadap suatu antibiotik. Penelitian ini menggunakan 3 macam antibiotik dan 3 kali ulangan, yaitu perlakuan A (bakteri Aeromonas hydrophilla diberi antibiotik novobiocin, enrofloxacin baytril dan DD15 0129) dan perlakuan B (bakteri Edwardsiella tarda diberi antibiotik novobiocin, enrofloxacin baytril dan DD15 0129). Media yang digunakan adalah Muller Hinton Agar, Bakteri diisolasi kemedia MHA kemudian diberi antibiotik dan diinkubasi selama 24 jam. Analisis sensitivitas antibiotik ini untuk menentukan sensitivitas antibiotik dengan melihat zona hambatnya Hasil penelitian menunjukkan bahwa bakteri Aeromonas hydrophilla resisten terhadap antibiotik Novobiocin dan DD15 0129 serta sensitif terhadap antibiotik enrofloxacin baytril, dengan nilai rerata ukuran zona hambat untuk novobiocin $(0 \mathrm{~mm})$, DD15 0129 $(0 \mathrm{~mm})$ dan enrofloxacin baytril $( \pm 24 \mathrm{~mm})$. Sedangkan bakteri Edwardsiella tarda intermediet terhadap antibiotik DD15 0129 dan sensitif terhadap antibiotik novobiocin dan antibitotik enrofloxacin baytril, dengan nilai rerata zona hambat untuk antibiotik DD15 $0129( \pm 14,6 \mathrm{~mm})$, novobiocin $( \pm 29,3 \mathrm{~mm})$ dan enrofloxacin baytril $( \pm 24,6 \mathrm{~mm})$. Berdasarkan hasil penelitian maka untuk pengobatan bakteri Aeromonas hydrophilla bisa dengan menggunakan antibiotik enrofloxacin baytril, sedangkan untuk bakteri Edwardsiella tarda dapat dengan menggunakan novobiocin dan enrofloxacin baytril.
\end{abstract}

Kata kunci: Aeromonas Hydrophylla, Edwardsiella tarda, Antibiotik.

\section{PENDAHULUAN}

Bakteri Aeromonas hydrophilla merupakan bakteri patogen penyebab penyakit "Motil Aeromonas Septicemia" (MAS), terutama untuk spesies ikan air tawar di perairan tropis (Rahmaningsih, 2012). Menurut Lukistyowati dan Kurniasih (2011), penyakit yang disebabkan oleh infeksi bakteri pada ikan khususnya yang disebabkan oleh $A$. hydrophilla mulai dikenal di Indonesia sekitar tahun 1980, dimana bakteri ini menyebabkan wabah penyakit pada ikan karper di wilayah Jawa Barat dan menyebabkan kematian sebanyak 125 ton. Di tahun yang sama kejadian serupa juga terjadi dan menyerang spesies ikan mas, penyakit tersebut dikenal dengan penyakit 'Ulcerative disease' atau penyakit borok / penyakit merah yang mengakibatkan kematian sekitar kurang lebih 173 ton jenis ikan mas termasuk didalamnya $30 \%$ ikan-ikan kecil/ benih mati disebabkan oleh bakteri Aeromonas sp. dan Pseudomonas sp., mengakibatkan 
kerugian sekitar Rp. 126 juta. Penyakit ini dapat menyebabkan sistemik yang menimbulkan kematian ikan yang tinggi, menyerang ikan-ikan budidaya dan dalam waktu singkat menyebar kedaerah lain.

Edwardsiella tarda merupakan bakteri gram negatif aerobik fakutatif tergabung dalam Enterobacteriaceae, dan patogen yang menyebabkan enterohaemorrahagic septicaemic disease pada ikan konsumsi (N.K. Maiti et al., 2009). Menurut (Acharya et al., 2007), Perkembangan infeksi E. tarda sangat lambat. Pada beberapa kasus, kematian akibat serangan bakteri ini sangat rendah yaitu kurang dari 5\%, tetapi pada beberapa kasus menunjukkan gejala penyakit yang tampak nyata dan menimbulkan kematian hingga 50\%. Salah satu faktor terjadinya serangan bakteri $E$. tarda adalah karena ikan mengalami stress, terutama akibat terlalu padat menjelang panen, kondisi kualitas air yang jelek dan tingginya bahan organik. Beberapa kasus telah dilaporkan ditemukan menyerang pada beberapa spesies ikan seperti Chinok salmon, channel catfish, mullet dan karper/ mas, selain itu juga telah berasosiasi dengan penyakit pada manusia.

Untuk mengantisipasi kemungkinan tersebarnya penyakit Aeromonas hydrophilla dan Edwardsiella tarda, maka perlu dilakukan usaha penanggulangan terutama melalui pengobatan dengan antibiotik untuk ikan yang terinfeksi. Antibiotik dapat bersifat bakterisidal atau bakteriostatik. Jika aktivitas terhadap suatu patogen mengakibatkan kematian patogen, maka obat itu mempunyai aktivitas bakterisidal, sebaliknya obat hanya menghambat pertumbuhan patogen maka dikatakan bahwa obat itu mempunyai aktivitas bakteriostatik (Anonim, 2010 b). Untuk mendapatkan antibiotik yang tepat dalam penggunaannya, maka perlu dilakukan uji coba berbagai macam antibiotik.

Pada umumnya metode yang dipergunakan dalam uji sensitivitas bakteri adalah metode Difusi Agar yaitu dengan cara mengamati daya hambat pertumbuhan mikroorganisme oleh ekstrak yang diketahui dari daerah di sekitar kertas cakram (paperdisk) yang tidak ditumbuhi oleh mikroorganisme. Zona hambatan pertumbuhan inilah yang menunjukkan sensitivitas bakteri terhadap bahan anti bakteri (Jawelz, 1995). Tujuan dari proses uji sensitivitas ini adalah mengetahui obat-obat yang paling cocok untuk kuman penyebab penyakit terutama pada kasus-kasus penyakit yang kronis dan untuk mengetahui adanya resistensi terhadap berbagai macam antibiotik. Penyebab kuman resisten terhadap antibiotik yakni memang kuman tersebut resisten terhadap antibiotik yang diberikan, akibat pemberian dosis dibawah dosis pengobatan dan akibat penghentian obat sebelum kuman tersebut betul-betul terbunuholeh antibiotik (Dwidjoseputro, 1998).

Sensitivitas bakteri terhadap antibiotik tergantung kepada kemampuan antibiotik tersebut untuk menembus dinding sel bakteri. Antibiotik lebih banyak yang efektif bekerja terhadap bakteri Gram positif karena permeabilitas dinding selnya lebih tinggi dibandingkan bakteri Gram negatif. Jadi suatu antibiotik dikatakan mempunyai spectrum sempit apabila mampu menghambat pertumbuhan bakteri Gram positif, sedangkan antibiotik berspektrum luas jika pertumbuhan bakteri Gram positif dan bakteri Gram negatif dapat dihambat oleh antibiotik tersebut (Sumadio et al., 1994). 


\section{METODE PENELITIAN}

Penelitian dilaksanakan selama 34 hari, mulai tanggal 04 Mei sampai dengan 08 Juni 2018. Penelitian dilakukan di Balai Karantina Ikan Pengendalian Mutu dan Keamanan Hasil Perikanan Jakarta II (Balai KIPM Jakarta II), Jl. Swasembada Timur XIII No. 64, Tanjung Priok, Jakarta Utara.

Peralatan yang akan digunakan pada penelitian adalah timbangan analitik, pinset, cawan petri, tabung reaksi, rak tabung reaksi, autoklaf, oven, magnetik stirer, lampu bunsen, jarum ose, laminary air flow, inkubator, mikroskop, erlenmeyer, beaker glass, gelas ukur, vortex mixer, loop, penggaris, peralatan pendukung lainya seperti alat tulis, formulir kegiatan penelitian, alat dokumentasi.

Bahan - bahan yang akan dipergunakan adalah isolat bakteri Edwardsiella tarda (NCIMB 2056) dan Aeromonas hydrophila (ATCC 35654 PK 5) yang diperoleh dari Balai Uji Standar Karantina Ikan Pengendalian Mutu Dan Keamanan Hasil Perikanan (BUSKIPM), antibiotik novobiocin (NV), DD15 0129, enrofloxacin baytril (ENR), seperangkat bahan untuk pengecatan gram (crystal violet, lugol iodine, alkohol 95\% dan safranin), bahan-bahan untuk uji biokimia identifikasi bakteri Edwardsiella tarda dan Aeromonas hydrophilla $\left(\mathrm{H}_{2} \mathrm{O}_{2}\right.$, oksidase tes, kovaks, Motility Indol Ornithin, Lysine Iron Agar), Oksidase Fermentasi medium, Tryptic Soy Iron Agar, MRVP medium, TCBS medium, glukosa, maltosa, sukrosa, laktosa, sorbitol, arabinosa, manitol dan lain sebagainya), serta bahan habis pakai seperti tissue, sarung tangan, masker dan akuades.

Uji Karakteristik isolat untuk memastikan bakteri yang digunakan positif bakteri Edwardsiella tarda dan Aeromonas hydrophilla dengan cara uji biokimia. Uji biokimia dilakukan dengan mengamati beberapa karakteristik biokimia sel bakteri. Pengujian terhadap karakteristik meliputi uji katalase, oksidase fermentative (OF), oksidase, uji produksi H2S, uji hidrolisis gelatin, uji methyl red (MR test), uji Voges Proskauer (Vptest), uji indhol, dan ornithine (faddin, 1980). Isolat berasal dari Balai Uji standar Karantina Ikan dan Pengendalian Mutu Hasil Perikanan (BUSKIPM) Jakarta sebagai sumber isolat yang dipergunakan dalam penelitian.

Isolat bakteri hasil uji karaktaristik setelah positif bakteri Edwardsiella tarda dan Aeromonas hydrophilla kemudian diperbanyak dengan cara dipupuk dimedia Mueller Hinton Agar (MHA) kemudian diinkubasi selama 24 jam pada suhu $37{ }^{\circ} \mathrm{C}$. Isolat murni siap untuk digunakan uji sensitivitas.

Uji sensitifitas bakteri terhadap antibiotik dengan menggunakan media MHA. Isolat bakteri Edwardsiella tarda dan Aeromonas hydrophilla yang telah diperbanyak sebelumnya diulaskan kembali pada media MHA dengan menggunakan jarum ose sampai rata, kemudian lempengan diskus antibiotik diletakkan diatas media agar tersebut. Antibiotik yang digunakan adalah novobiocin (NV), DD15 0129, enrofloxacin baytril (ENR). Masing masing bakteri diulang sebanyak 3 kali untuk melihat perbandingannya. Jadi total media MHA yang digunakan sebanyak 6 petri. Media kemudian diinkubasi selama 24 jam pada suhu $37{ }^{0} \mathrm{C}$. Pengamatan dilakukan dengan cara mengukur diameter zona hambatan pertumbuhan bakteri pada sekitar lempengan cakram (diskus) antibiotika. Pengamatan dengan cara mengukur diameter zona hambat dalam mm. Diameter zona hambat dapat diperoleh dengan cara mengukur jari-jari zona hambat dengan menggunakan mistar dan hasilnya dikalikan dua untuk 
mendapatkan diameter zona hambat (Ravel, 1978). Uji sensitivitas mengacu pada ketentuan Clinical and Laboratory Standards Institute (CLSI, 2012) dimana nilai $\leq 12 \mathrm{~mm}$ (Resisten), 13-16 mm (Intermediet), dan $\geq 17 \mathrm{~mm}$ (Sensitif).

Metode pengumpulan data dilakukan dengan mengambil 2 data yang meliputi data primer dan data sekunder. Data primer atau data tangan pertama adalah data yang diperoleh secara langsung dari subjek penelitian dengan menggunakan alat pengukur atau alat pengambilan data langsung pada subjek sebagai sumber informasi yang dicari. Data primer meliputi mengambil bakteri, menanam bakteri dan mengamati bakteri. Data sekunder adalah data tangan kedua yaitu data yang diperoleh dari pihak lain, yang tidak langsung diperoleh dari subjek yang diteliti. Data sekunder dapat diperoleh dari studi-studi sebelumnya yang dikumpulkan dan disatukan atau yang diterbitkan oleh berbagai instansi lain misal biro statistika, majalah, keterangan-keterangan atau publikasi lainnya.

\section{HASIL DAN PEMBAHASAN}

Uji isolat dan identifikasi bakteri bertujuan untuk memastikan bahwa isolat bakteri yang diperoleh dari Balai Uji Standar Karantina Ikan Pengendalian Mutu Dan Keamanan Hasil Perikanan (BUSKIPM) dengan kode 05 B untuk bakteri Aeromonas hydrophilla (ATCC 35654 PK 5) dan kode 168 B untuk bakteri Edwardsiella tarda (NCIMB 2056) dan yang digunakan dalam penelitian merupakan bakteri Edwardsiella tarda dan Aeromonas hydrophilla.

Kultur bakteri dilakukan untuk mengetahui pertumbuhan bakteri dan untuk memperoleh biakan murni dari suatu jenis bakteri tunggal. Bakteri dengan kode 05 B dan bakteri dengan kode 168 B diisolasi dimedia TSA (Triptic Soy Agar), Mac Conkey dan BGA (Briliant Green Agar), kemudian diinkubasi selama $24-48$ jam pada suhu $20-25^{\circ} \mathrm{C}$. Hasil isolasi dimedia TSA, Mac Conkey dan BGA disajikan pada Tabel berikut.

Tabel 1. Hasil Isolasi Bakteri Pada Media TSA, Mac Conkey dan BGA

\begin{tabular}{|c|l|c|c|c|}
\hline \multirow{2}{*}{ NO } & \multicolumn{1}{|c|}{ Jenis Sampel } & TSA & Mac Conkey & BGA \\
\cline { 3 - 5 } 1 & $\begin{array}{l}\text { Isolat kode 05 B } \\
\text { (Aeromonas hydrophila) })\end{array}$ & Cream & $\begin{array}{c}\text { Tidak berwarna } \\
\text { (Transparan) }\end{array}$ & Merah \\
\hline 2 & $\begin{array}{l}\text { Isolat kode 168 B } \\
(\text { Edwardsiella tarda })\end{array}$ & Cream & $\begin{array}{c}\text { Tidak berwarna } \\
\text { (Transparan) }\end{array}$ & Pink Pucat \\
\hline
\end{tabular}

Berdasarkan tabel diatas isolat dengan kode 05 B diperoleh koloni yang tumbuh tidak berwarna (transparan) pada media TSA dan Mac Conkey sedangkan pada media BGA koloni yang tumbuh berwarna merah. Sedangkan isolat dengan kode 168 B diperoleh koloni yang tumbuh tidak berwarna (transparan) pada media TSA dan Mac Conkey sedangkan pada media BGA koloni yang tumbuh berwarna pink pucat. Hal ini sesuai Bergey (1994) bahwa bakteri Aeromonas hydrophilla pada media TSA dan Mac conkey tidak berwarna (transparan) sedangkan pada media BGA koloni akan berwarna merah. Sedangkan bakteri Edwardsiella tarda pada media TSA dan Mac conkey tidak berwarna (transparan) sedangkan pada media BGA koloni akan berwarna pink pucat. 
Data hasil pengukuran zona hambat $(\mathrm{mm})$ dari uji sensitivitas bakteri terhadap antibiotika novobiocin, enrofloxacin baytril dan DD15 0129 disajikan pada Tabel dan gambar berikut.

\begin{tabular}{|c|c|c|c|c|c|c|}
\hline \multirow[b]{2}{*}{$\begin{array}{l}\mathrm{N} \\
\mathrm{O}\end{array}$} & \multirow[b]{2}{*}{ Kode Isolat } & \multirow[b]{2}{*}{ Antibiotik } & \multicolumn{3}{|c|}{ Ulangan } & \multirow{2}{*}{$\begin{array}{l}\text { Rata } \\
\text { Rata }\end{array}$} \\
\hline & & & 1 & 2 & 3 & \\
\hline \multirow{3}{*}{1} & \multirow{3}{*}{$\begin{array}{l}\text { Aeromonas } \\
\text { hydrophilla }\end{array}$} & Novobiocin $(30 \mu \mathrm{g})$ & 0 & 0 & 0 & 0 \\
\hline & & Enrofloxacin $(5 \mu \mathrm{g})$ & 25 & 23 & 24 & 24 \\
\hline & & DD15 $0129(150 \mu \mathrm{g})$ & 0 & 0 & 0 & 0 \\
\hline \multirow{3}{*}{2} & \multirow{3}{*}{$\begin{array}{l}\text { Edwardsiella } \\
\text { tarda }\end{array}$} & Novobiocin $(30 \mu \mathrm{g})$ & 30 & 28 & 30 & 29,3 \\
\hline & & Enrofloxacin $(5 \mu \mathrm{g})$ & 25 & 24 & 25 & 24,6 \\
\hline & & DD15 $0129(150 \mu \mathrm{g})$ & 13 & 15 & 16 & 14,6 \\
\hline
\end{tabular}

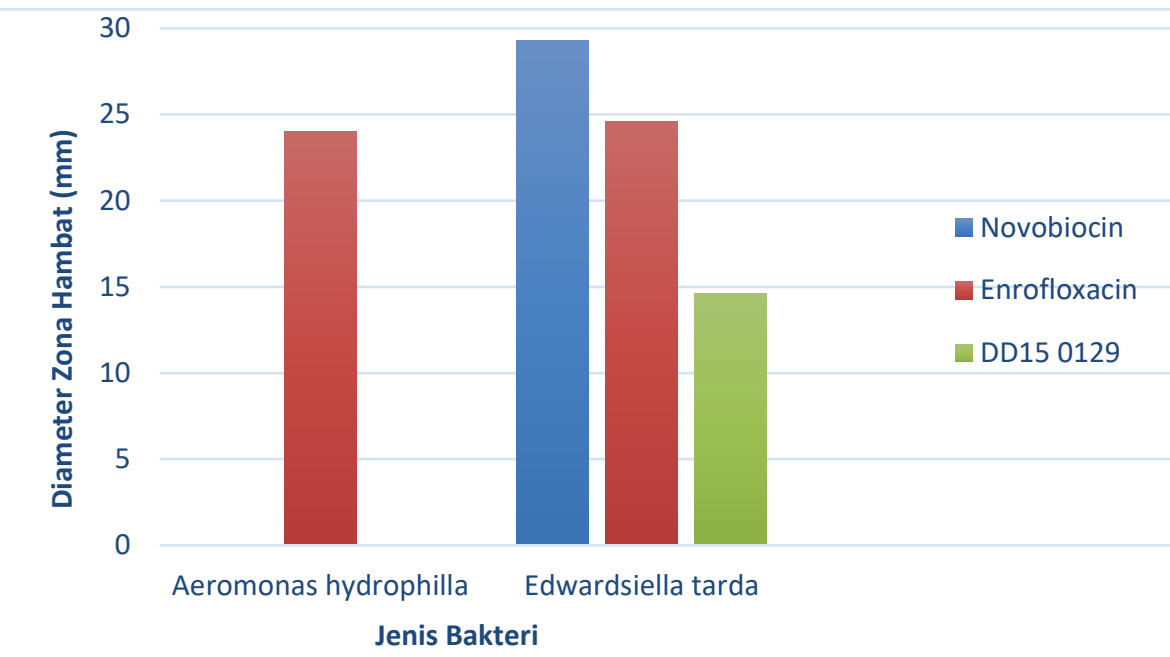

Data hasil kriteria zona hambat $(\mathrm{mm})$ pada uji sensitivitas bakteri terhadap antibiotika novobiocin, enrofloxacin baytril dan DD15 0129 disajikan pada Tabel dan Gambar Berikut

\begin{tabular}{|c|c|c|c|c|c|c|}
\hline \multirow[b]{2}{*}{ No } & \multirow[b]{2}{*}{ Kode Isolat } & \multirow[b]{2}{*}{ Antibiotik } & \multicolumn{3}{|c|}{ Ulangan } & \multirow{2}{*}{ Kesimpulan } \\
\hline & & & 1 & 2 & 3 & \\
\hline \multirow[t]{3}{*}{1} & \multirow{3}{*}{$\begin{array}{l}\text { Aeromonas } \\
\text { hydrophilla }\end{array}$} & Novobiocin $(30 \mu \mathrm{g})$ & $\mathrm{R}$ & $\mathrm{R}$ & $\mathrm{R}$ & $\mathrm{R}$ \\
\hline & & Enrofloxacin $(5 \mu \mathrm{g})$ & $\mathrm{S}$ & $\mathrm{S}$ & $\mathrm{S}$ & $\mathrm{S}$ \\
\hline & & DD15 $0129(150 \mu \mathrm{g})$ & $\mathrm{R}$ & $\mathrm{R}$ & $\mathrm{R}$ & $\mathrm{R}$ \\
\hline \multirow[t]{3}{*}{2} & \multirow{3}{*}{$\begin{array}{l}\text { Edwardsiella } \\
\text { tarda }\end{array}$} & Novobiocin $(30 \mu \mathrm{g})$ & $\mathrm{S}$ & $S$ & $\mathrm{~S}$ & $\mathrm{~S}$ \\
\hline & & Enrofloxacin $(5 \mu \mathrm{g})$ & $S$ & $\mathrm{~S}$ & $\mathrm{~S}$ & $S$ \\
\hline & & DD15 $0129(150 \mu \mathrm{g})$ & $\mathrm{I}$ & $\mathrm{I}$ & $\mathrm{I}$ & $\mathrm{I}$ \\
\hline
\end{tabular}

Ket: $(\mathrm{R}=$ Resisten, $\mathrm{I}=$ Intermediet, $\mathrm{S}=$ Sensitif $)$

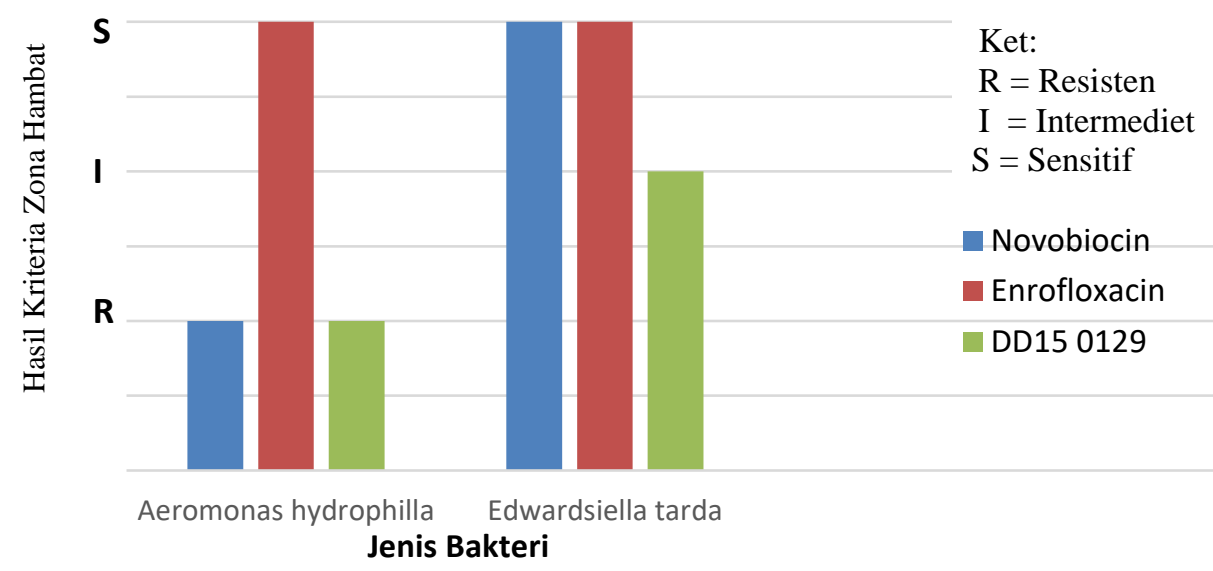


Berdasarkan hasil pengukuran zona hambat Tabel diatas dan mengacu pada CLSI (2012), bahwa diameter $\leq 12 \mathrm{~mm}$ (Resistance), 13-16 mm (Intermediate), dan $\geq 17$ mm (Sensitive). Maka, nilai rerata pengukuran zona hambat bakteri Aeromonas hydrophilla terhadap antibiotik kategorisasi resisten adalah pada antibiotik novobiocin $(0 \mathrm{~mm})$ dan DD15 $0129(0 \mathrm{~mm})$ dan kategorisasi sensitif adalah pada antibiotik enrofloxacin $( \pm 24 \mathrm{~mm})$. Sedangkan nilai rerata pengukuran zona hambat bakteri Edwardsiella tarda terhadap antibiotik kategorisasi intermediet adalah pada antibiotik DD15 $0129( \pm 14,6 \mathrm{~mm})$ dan kategorisasi sensitif adalah pada antibiotik novobiocin $( \pm 29,3 \mathrm{~mm})$ dan antibitotik enrofloxacin $( \pm 24,6 \mathrm{~mm})$. Bakteri Aeromonas hydrophilla sensitif terhadap antibiotika enrofloxacin $( \pm 24$ $\mathrm{mm})$.

\section{KESIMPULAN DAN SARAN}

Berdasarkan hasil penelitian bakteri Aeromonas hydrophilla resisten terhadap antibiotik novobiocin dan DD15 0129 serta sensitif terhadap antibiotik enrofloxacin, dengan nilai rerata ukuran zona hambat untuk Novobiocin $(0 \mathrm{~mm})$, DD15 $0129(0 \mathrm{~mm})$. Enrofloxacin $( \pm 24 \mathrm{~mm})$. Sedangkan bakteri Edwardsiella tarda intermediet terhadap antibiotik DD15 0129 dan sensitif terhadap antibiotik novobiocin dan antibitotik enrofloxacin, dengan nilai rerata zona hambat untuk antibiotik DD15 $0129( \pm 14,6 \mathrm{~mm})$, novobiocin $( \pm 29,3 \mathrm{~mm})$ dan enrofloxacin $( \pm 24,6 \mathrm{~mm})$.

Untuk pengobatan bakteri Aeromonas hydrophilla bisa dengan menggunakan antibiotik enfrafloxacin, sedangkan untuk bakteri Edwardsiella tarda dapat dengan menggunakan novobiocin dan enrofloxacin. Sedangkan banyaknya dosis yang digunakan maka perlu dilakukan penelitian lebih lanjut.

\section{DAFTAR PUSTAKA}

Acharya, D, Anshu. 2007. Indigenous Herbal Medicines: Tribal Formulation and Traditional Herbal Practices. Jaipur: Aavishkar Publisher Distributor.

Afrianto. E., Liviawaty. E., Jamaris. dan Z., Hendi. 2015. Penyakit Ikan. Penebar Swadaya. Jakarta.

Anonim.2010 a. Keputusan Menteri Kelautan dan Perikanan Republik Indonesia Nomor KEP.03/MEN/2010. Tentang Penetapan Jenis-jenis Hama dan Penyakit Ikan Karantina, Golongan, Media, Pembawa, dan Sebarannya. 7 halaman.

Anonim. 2010 b. Antibiotika dan Penggunaannya Module 3. Trovan Training Program Pfizer.

Austin,B and D.A Austin. 1987. Bacterial fish Phatogens Diseases in Farmed and Wild Fish. Jhon Willey and Sons Ltd. England.

Baird, K.D., Chikarmane, H.M., Smolowitz, R. and Uhlinger,K.R. .2003. Detection of Edwardsiella infections in Opsanus by polymerase chain reaction. Biol Bull 205, 235-236.

Buller, Nicky B. 2004. Bacteria from Fish and Other Aquatic Animals: A Practical Identification Manual.Cambridge,USA. Cabi Publishing. Retrieved 
Clinical and Laboratory Standards Institute. 2012. Performance Standards for Antimicrobial Susceptibility Testing; Twenty-Second Informational Supplement. (26) $3: 16$ - 188.

Djide M, Natsir. 2008. Dasar-dasar Mikrobiologi. Universitas Hasanuddin. Makassar.

Djide M,. N., Sartini., Syahruddin kadir H. 2003. "Mikrobiologi Farmasi Terapan", Universitas Hasanuddin , Makassar.

Dwidjoseputro. 1998. Dasar-Dasar Mikrobiologi. Jakarta : Djambatan

Fadhlan. 2010. Mikrobiologi Farmasi. Salemba medika. Jakarta.

Gaman, P. M., dan Sherrington, K. B. 1992. Ilmu Pangan : Pengantar Ilmu Pangan, Nutrisi, dan Mikrobiologi, Edisi Kedua, Yogyakarta, UGM Press.

Ganiswarna, Sulistia G. 1995. Farmakologi dan Terapi, UI Press, Jakarta

Holt, Jhon g, Noel R. Krieg, Peter H.A. Snealth, James T. Stanley, Stanley T. Williams, 1994. Bergey's Manual of determinative Bacteriology. Ninth Edition.

Jawelz, G., Melnick, J. L., dan Adelberg, E. A. 1995. Mikrobiologi untuk Profesi Kesehatan. Jakarta, EGC

Jawet, E. 1998. Prinsip Kerja Obat Antimikroba : In Katzung B, eds. Farmakologi Dasar dan Klinik. Jakarta : EGC. 100 pp.

Jawetz, dkk. 2001. Mikrobiologi Kedokteran. Jakarta, Penerbit Salemba Medika

Jean F. Mac Faddin, MS, MT (ASCP), SM (AAM), SFC, USA Retired, 1980. Biochemichal Tests for Identification of Medical Bacteria. Second Edition.

Kabata Z. 2005. Parasites and Diseases of Fish Cultured in The Tropics. Taylor and Francis Ltd. London.

Khargaria S, Barua CC, Mohan P, Bhattacharya M. 2005. Pharmacokinetic studies Enrofloxacin in Yak after Intramuscular Administration. Iran J Pharmacol Ther. 4(2):91-94.

Lukistyowati, I dan Kurniasih. 2011. Kelangsungan Hidup Ikan Mas (Cyprinus carpio L) yang diberi Pakan Ekstrak Bawang Putih (Allium sativum) dan di Infeksi Aeromonas hydrophila. Jurnal Perikanan dan Kelautan, 16,1 (2011) : 144-160

Lukistyowati, I dan Kurniasih. 2012. Pelacakan Gen Aerolysisn dari Aeromonas hidrophyla pada Ikan Mas yang diberi Pakan Ekstrak Bawang Putih. Jurnal Veteriner, Vol. 13 No. $1: 43-50$

MacFaddin J.F. 1980 - Biochemical Tests for Identification of Medical Bacteria Williams and Wilkins, Baltimore,USA, 527.

N.K. Maiti, Nema., Sarkar, B.K, Mukherjee, P.K, 2009. Determination of trace and heavy metals in some commonly used medical herns in Ayurveda. Toxical Ind Health.

Plumb J A .1999. Health maintenance and principal microbial diseases of cultured fish,Ames: Iowa State University Press In: B R Mohanty and P K Sahoo, 2007, Edwardsiellosis in fi sh: a brief review, J. Biosci. 32 13311344]

Prapti, 2012. Antibiotik Alami untuk Mengatasi Aneka Penyakit. Agro Media Pustaka. Jakarta.

Pratiwi, T Sylvia., 2008. Mikrobiologi Farmasi. Erlangga. Jakarta.

Puskari, 2010. Serangan Edwardsiella Tarda terhadap ikan yang terinfeksi. 
Rahmaningsih, S. 2012. Penagruh Ekstrak Sidawayah dengan Konsentrasi yang Berbeda untuk Mengatasi Infeksi Bakteri Aeromonas hydrophyla pada Ikan Nila (Oreochromis niloticus). Jurnal Ilmu Perikanan dan Sumberdaya Perairan

Ravel, R. 1978. Clinical Laboratory Medical. Clinical Application of Laboratory Data. $3^{\text {rd }}$ ed. Year Book Medical Publishers, Inc. Chicago.

Samsudari S, 2006. Pengujian ekstrak temulawak dan kunyit terhadap resistensi bakteri Aeromonas hydrophilla yang menyerang ikan mas ( Cripinus carpio).

Sanoesi, E. 2008. Penggunaan Ekstrak Daun Pepaya (Carica papaya Linn) terhadap Jumlah Sel Makrofag pada Ikan Mas (Cyprinus carpio L) yang Terinfeksi Bakteri Aeromonas hydrophila. Jurnal Penelitian Perikanan, Vol 11, No. 2, Desember 2008.

Sjahrurachman, A.2011. Cara Genetis untuk Menentukan Kepekaan Bakteri terhadap Antibiotik, CDK 188. 38 (7): 498 - 502.

Sukenda, L., Jamal, Wahyuningrum, D. dan Hasan, J. 2008. Penggunaan Kitosan untuk Pencegahan Infeksi Aeromonas hydrophilla pada Ikan Lele Dumbo Clarias sp. Jurnal Akuakultur Indonesia. (7)2: 159 - 169.

Sumadio, H. 2004. Biokimia dan Farmakologi Antibiotika, USU Press, Medan.

Suwandi, U. 2003. Perkembangan Antibiotik. Cermin Dunia Kedokteran No. 83. Pusat Penelitian dan Pengembangan PT. Kalbe Farma, Jakarta.

Triyanto, 1990. Patologi dan Patogenitas beberapa isolate bakteri Aeromonas hydrophilla terhadap ikan lele (Clarias batracus). Seminar Nasional ke-II Penyakit Ikan dan Udang, Bogor 16 - 18 Januari 1990.

Utami, Prapti., 2012. Antibiotik Alami untuk Mengatasi Aneka Penyakit. Agro Media Pustaka. Jakarta.

Waluyo, Lud. 2008. Teknik dan Metode Dasar Dalam Mikrobiologi. Malang. UMM Press. 